\title{
Assessment of the quality and quantity of naturally induced antibody responses to EBA175RIII-V in Ghanaian children living in two communities with varying malaria transmission patterns
}

Hamza B. Abagna ${ }^{1,2}$, Festus K. Acquah1', Ruth Okonu', Nii A. Aryee ${ }^{2}$, Michael Theisen $^{3,4}$ and Linda E. Amoah ${ }^{1 *}$ (D)

\begin{abstract}
Background: Recent global reports on malaria suggest significant decrease in disease severity and an increase in control interventions in many malaria endemic countries, including Ghana. However, a major driving force sustaining malaria transmission in recent times is the asymptomatic carriage of malaria parasites, which can enhance immune responses against parasite antigens. This study determined the prevalence and relative avidities of naturally induced antibodies to EBA175RIII- $V_{L}$ in asymptomatic children living in two communities with varying malaria transmission patterns.
\end{abstract}

Methods: An asexual stage Plasmodium falciparum antigen, EBA175RIII- $V_{\mathrm{LI}}$ was expressed in Lactococcus lactis, purified and used in indirect ELISA to measure total and cytophilic IgG concentrations and avidities in children aged between 6 and 12 years. The children were selected from Obom and Abura, communities with perennial and seasonal malaria transmission, respectively. Venous blood samples were collected in July and October 2015 and again in January 2016. The multiplicity of infection and the genetic diversity of EBA175RIII circulating in both sites were also assessed using polymerase chain reaction.

Results: Asymptomatic parasite carriage in the children from Obom decreased from July (peak season), through October and January, however parasite carriage in children from Abura was bimodal, with the lowest prevalence estimated in October. Antibody concentrations over the course of the study remained stable within each study site however, children living in Obom had significantly higher EBA175RIII- $V_{L I}$ antibody concentrations than children living in Abura $\left(P<0.05\right.$, Mann-Whitney test). Over the course of the study, the relative antibody avidities of EBA175RIII- $V_{L I}$ IgG antibodies were similar within and between the sites.

Conclusion: Naturally acquired lgG concentrations but not relative antibody avidities to EBA175RIII-V were significantly higher in Obom where malaria transmission is perennial than in Abura, where malaria transmission is seasonal.

Keywords: Malaria, Plasmodium falciparum, ELISA, Asymptomatic, Antibodies, Avidity, Transmission

\footnotetext{
*Correspondence: lamoah@noguchi.ug.edu.gh

1 Noguchi Memorial Institute for Medical Research, University of Ghana,

Accra, Ghana

Full list of author information is available at the end of the article
} 


\section{Background}

Morbidity and mortality rates associated with malaria in sub-Saharan Africa although on the decline over the past few years, are still very high and a major public health concern [1]. Exposure to infection by Plasmodium falciparum, the major causative parasite for malaria in sub-Saharan Africa, results in the development of antidisease immunity [1] as well as non-sterile anti-parasite immunity, which can protect against high parasitaemia [2]. Maturity of immunity to malaria enables the host to harbour previously encountered $P$. falciparum parasite clones without showing signs of malaria [3-5]. Asymptomatic parasite carriage can be either microscopic or submicroscopic and may persist for extended periods $[6$, 7] and serve as reservoirs for malaria transmission as no treatment is sought [8].

Antibodies developed against a number of asexual $P$. falciparum sporozoite and merozoite antigens have been determined to be protective in humans $[9,10]$. The erythrocyte binding antigen 175 (EBA 175, Pf3D7_0731500) is a $P$. falciparum merozoite ligand that is implicated in erythrocyte invasion, as it is used by the parasite to bind to erythrocytes through interactions with the sialic acid residues of glycophorin $A$ on the erythrocyte during merozoite invasion [11, 12]. EBA175 consists of 6 extracellular regions, R1 through RVI [13]. RII, which consists of two cysteine rich Duffy binding domains, F1 and F2 which have been identified as essential for receptor binding [12] has been produced as a recombinant antigen in Escherichia coli [14], Baculovirus [15] and Pichia pastoris [16]. Naturally acquired antibody responses against recombinant RII have been suggested to inhibit the merozoite binding to glycophorin $\mathrm{A}$, inhibit invasion in vitro and provide protection against clinical malaria [11, 12 , 16-20]. RIII-IV comprises of a dimorphic region, RIII, which is used to distinguish between the FCR3 ' $\mathrm{F}$ ' and CAMP ' $C$ ' parasite variants [13] as well as the highly conserved RIV and RV regions [7]. EBA175RIII-V has been expressed in $E$. coli $[11,17,21]$ and naturally-induced antibodies against the RIII-V region [20, 21] have been suggested to offer protection against disease in some studies [17, 22]. Antibodies against region IV-V of EBA 175 have been shown to have strain transcending growth inhibitory properties, which are more potent than antibodies against the RII region [23] and more significantly correlated with protection against clinical malaria in children [24]. A recent report suggests that antibodies against RIII-V offer similar levels of protection as a 200fold excess of antibodies against RII [25], suggesting antibodies against RIII-V are more potent than antibodies against RII.

Exposure to malaria parasites in perennial transmission settings is expected to be higher than in seasonal transmission settings. Repeated exposure to malaria antigens is expected to increase antibody affinity and result in an increase in antibody avidity [26], however, some reports on avidity of malaria antibodies have suggested otherwise. One report has suggested that increased exposure to $P$. falciparum parasites did not result in an increase in the relative antibody avidity to merozoite antigens including MSP1 and MSP3 [26]. An earlier study on Gambian children also failed to find an association between asymptomatic $P$. falciparum carriage and antibody avidity [27] despite the fact that asymptomatic infections repeatedly expose the host to the parasite, which should boost immune responses and enhance affinity maturation. These studies put together suggest that more studies are needed to understand the functions of anti-EBA175RIII-V antibodies as well as understand how antibody concentrations and avidity influence asymptomatic $P$. falciparum carriage.

In this study, a new recombinant linear fragment of EBA175RIII-V, EBA175RIII- $\mathrm{V}_{\mathrm{Ll}}$ was produced in Lactococcus lactis and used to monitor changes in the quality and quantity of naturally acquired anti-EBA175 antibodies in school children aged between 6 and 12 years, living in two communities of varying malaria parasite prevalence in southern Ghana.

\section{Methods}

\section{Study site and population}

A multiple cross-sectional study was conducted on a cohort of 137 children aged between 6 and 12 years. The children were recruited from two public primary schools, one in Obom, in the Obom Domeabra constituency of the Greater Accra Region, and the other in Abura in the Cape Coast metropolis of the Central Region (Fig. 1), both within the coastal savanna zone of Ghana. The peak malaria season in both sites is between July and August but malaria transmission in Obom is perennial and seasonal in Abura [28]. None of the children who were sampled exhibited any signs of clinical malaria.

\section{Sample collection and processing}

The children recruited in this study were part of a larger study where children were recruited into a multiple cross-sectional study that began in February 2015 and ended in January 2016. A total of 64 children from Obom and 73 children from Abura who were present during the July 2015 (peak malaria season), October 2015 (end of peak season) and January 2016 (off peak season) sampling visits were selected for this study. During each collection, $5 \mathrm{ml}$ of venous blood was collected into acid citrate dextrose (ACD) vacutainer tubes and used to prepare thin and thick blood smears (for species identification and parasite density estimation, respectively) as 


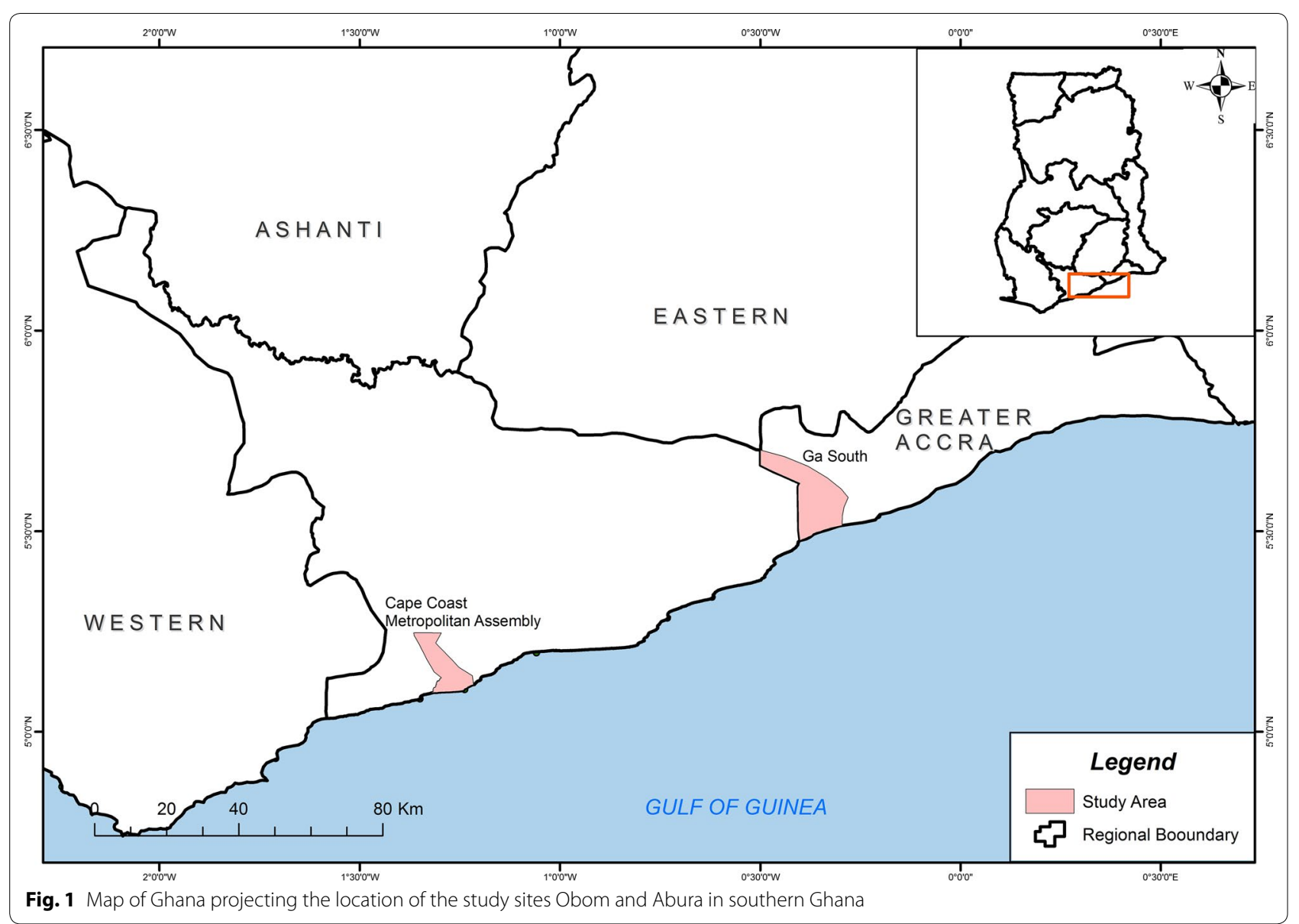

well as to spot filter paper. The filter paper samples were air-dried and stored desiccated at room temperature for DNA extraction within a week of the collection. Plasma was separated by centrifugation from the whole blood and stored frozen at $-20{ }^{\circ} \mathrm{C}$ until required.

\section{Estimation of parasite density}

Thick and thin blood smears were processed and observed under $\times 100$ oil immersion using a light microscope [29]. The blood smears were subsequently read by two independent microscopists. The number of infected erythrocytes was counted against 200 white blood cells (WBCs) and then multiplied by 40, based on the assumption that $1 \mu \mathrm{l}$ of blood contains 8000 WBCs to yield the parasite density [30]. Plasmodium species identification was based on morphological differences between species.

\section{Parasite genotyping}

\section{Extraction of genomic DNA}

DNA extraction was carried out using the Chelex extraction method as previously described [31] with minor modifications. Briefly, two discs of the dried filter paper blood-spots (DBS) were punched using a $3 \mathrm{~mm}$ paper punch into a $1.5 \mathrm{ml}$ microcentrifuge tube containing $1120 \mu \mathrm{l}$ of $0.5 \%$ saponin $(0.5 \mathrm{~g}$ saponin (Sigma-Aldrich, USA) in $100 \mathrm{ml}$ phosphate buffered saline (SigmaAldrich, USA), pH 7.4 (PBS) solution. The tubes were vortexed and then left shaking on a shaking incubator overnight at room temperature. The saponin solution was subsequently decanted, the discs washed twice with $1 \mathrm{ml}$ of ice-cold PBS and centrifuged for $10 \mathrm{~min}$ at $10,000 \times g$. A $150 \mu \mathrm{l}$ aliquot of $6 \%$ Chelex-100 (Sigma-Aldrich, USA) in DNase/RNase-free water was added to each disc. After a 5 -min incubation at $95{ }^{\circ} \mathrm{C}$ the tubes were centrifuged at $14,000 \times g$ and the DNase/RNase-free water containing the extracted genomic DNA carefully pipetted into a labelled tube and stored at $-20{ }^{\circ} \mathrm{C}$ until further use.

\section{Molecular characterization of $P$. falciparum parasites}

Amplification of the 18sRNA from $P$. falciparum [32] was used to determine the prevalence of asymptomatic infection in children in each site during all the three sample collection time points. Briefly, the primary PCR reaction consisted of $5 \mu \mathrm{l}$ of genomic DNA (gDNA), $200 \mathrm{nM}$ 
dNTPs, $2 \mathrm{mM} \mathrm{MgCl}$, $133 \mathrm{nM}$ each of forward (rPLU6) and reverse (rPLU5) primers (Additional file 1) and $1 \mathrm{U}$ OneTaq DNA polymerase (New England Biolabs, UK). The nested PCR consisted of a similar reaction mix as the primary reaction, except that the primers were replaced with rFal1 (forward) and rFal2 (reverse) and $2 \mu \mathrm{l}$ of the primary product was used as the template. The positive control used for the speciation reaction was gDNA from the 3D7 strain of P. falciparum (MRA 102G).

The RIII domain of EBA175 (EBA175RIII) was amplified from DNA extracted from samples collected in July and October using semi nested PCR with primers listed in Additional file 1. Briefly, $4 \mu \mathrm{l}$ of genomic DNA (gDNA) was amplified using a PCR reaction mixture that consisted of $200 \mathrm{nM}$ dNTPs, $2 \mathrm{mM} \mathrm{MgCl}, 133 \mathrm{nM}$ each of forward and reverse primers ( $\mathrm{R} 3 \mathrm{~F}$ and $\mathrm{R} 5 \mathrm{R}$ for the primary reaction and R3F and R3R for the secondary reaction), and 0.5 units of One Taq DNA polymerase. PCR products were separated on $2 \%$ ethidium bromide-stained agarose gels and visualized under UV illumination. Genomic DNA for P. falciparum strains K1 (MRA 159G) and 3D7 (MRA 102G), obtained from MR4, were used as positive controls for the PCR genotyping reactions.

\section{Multiplicity of Plasmodium falciparum parasite infection}

The merozoite surface protein 1 ( $m s p 1$ ) and merozoite surface protein 2 (msp2) genes were amplified from the extracted DNA from samples collected in July using a similar process to that described in an earlier study [33]. Briefly, the highly polymorphic block 2 region of $m s p 1$ and block 3 of $m s p 2$ were amplified using family specific nested polymerase chain reaction (PCR). The primary $15 \mu \mathrm{l}$ reaction contained $\sim 10-50 \mathrm{ng}$ of extracted DNA, $0.2 \mathrm{mM}$ dNTP mix, $2 \mathrm{mM} \mathrm{MgCl}$, $0.2 \mathrm{mM}$ each of a combination of forward and reverse primers for both $m s p 1$ and $m s p 2$ and 0.5 units of OneTaq Polymerase. The family specific $m s p 1$ and $m s p 2$ secondary reactions mixture were similar to the primary, however, $1 \mu$ of the primary PCR product was used as template and family specific primers (Additional file 1) were used. A negative control (no template) and positive controls for each allelic family (msp1: MRA-159G for KI, MRA-155G for MAD20 and MRA-200G for the RO33, msp2: MRA-102G for 3D7 and MRA-155G for FC27) were included in the PCR reactions.

\section{Production of EBA175RIII- $V_{\mathrm{LI}}$}

The EBA175RIII-V fragment (2280-3900 bp) was amplified from gDNA extracted from the 3D7 P. falciparum parasite strain ('F' allele) and produced in L. lactis using the same expression vector and host as previously described for the production of Pfs $230_{\mathrm{LICO}}$ [34] and primers listed in Additional file 1. Briefly, the EBA 175 RIII-V gene was amplified from gDNA extracted from the 3D7 strain of $P$. falciparum using the $3 \mathrm{RF}$ and the R5R primers listed in Additional file 1. The PCR amplicon was subsequently treated with BglII and BamHI and purified using the DNA Clean \& Concentrator ${ }^{\mathrm{TM}}-25$ kit (Zymo). The vector, pLEA2 [35] was digested with BglII, dephosphorylated using alkaline phosphatase and purified from a $1 \%$ agarose gel. The vector and fragment were ligated using T4 DNA ligase, transformed into max efficiency DH5 $\alpha$ competent cells according to manufacturer's instructions and plated on LB plates containing $250 \mu \mathrm{g} /$ $\mathrm{ml}$ erythromycin. Colonies containing the EBA175RIII$\mathrm{V}$ plasmid were grown in selective media and plasmids isolated using the EZNA plasmid purification kit (Omega Biotek, USA) according to manufacturer's protocol. The plasmids were sent for commercial sequencing (Integrated DNA Technology, GE).

\section{Expression of EBA175-RIII- $V_{\mathrm{LI}}$}

A procedure similar to that previously described for the production of Pfs $230_{\mathrm{LIC} 0}$ [34] was used. Briefly, the pLEA2.EBA175RIII-V plasmid was transformed into competent L. lactis strain MG1363 using the Gene Pulser (BIORAD, USA). Transformed cells were then plated on Yeast Peptone Dextrose media (YPD) plates containing $5 \mu \mathrm{g} / \mathrm{ml}$ erythromycin and then incubated at $30^{\circ} \mathrm{C}$. Transformed L. lactis colonies were screened for protein expression by inoculating a colony into $5 \mathrm{ml}$ of YPD media supplemented with $10 \mu \mathrm{g} / \mu \mathrm{l}$ erythromycin overnight. The culture was subsequently harvested via centrifugation at $4500 \times g$ for $10 \mathrm{~min}$ and the supernatant subjected to SDS-PAGE analysis.

Large scale production of EBA175RIII- $\mathrm{V}_{\mathrm{Ll}}$ was prepared by inoculating a biofermentor $[35,36]$ containing $1 \mathrm{~L}$ of YPD supplemented with $10 \mu \mathrm{g} / \mu \mathrm{l}$ erythromycin and set at $30{ }^{\circ} \mathrm{C}$ and pH 6.5 with a clone of EBA175RIII$\mathrm{V}$. After $4-5 \mathrm{~h}$ of stationary phase growth $(\sim 14 \mathrm{~h}$ of total growth), the culture was harvested by centrifugation at $10,000 \times g$ for $20 \mathrm{~min}$.

\section{Protein purification and characterization}

The culture supernatant was clarified by filtration through a $20 \mu \mathrm{m}$ filter and then purified by affinity chromatography (AC) over a $5 \mathrm{ml}$ HisTrap Ni-NTA column (GE healthcare, USA) using an AKTAxpress purification system (GE healthcare, USA) with wash/equilibration buffer (50 mM sodium phosphate $\mathrm{pH} 7.0 / 250 \mathrm{mM}$ sodium chloride/20 mM imidazole) and elution buffer (wash buffer supplemented with $200 \mathrm{mM}$ imidazole).

A $15 \mu \mathrm{l}$ aliquot of the clarified culture supernatant as well as $15 \mu \mathrm{l}$ of a tenfold diluted affinity purified protein were subjected to SDS-PAGE analysis as previously described [34]. The gels were either stained with 
Coomassie blue or subjected to western blot analysis. The western blot was probed with penta-His mouse IgG1 monoclonal antibodies (Thermo Scientific, USA) followed by alkaline phosphatase conjugated goat anti mouse IgG $(\mathrm{H}+\mathrm{L})$ secondary antibodies (Thermo Scientific, USA). The blot was finally developed using 1-step nitro-blue tetrazolium and 5-bromo-4-chloro3 '-indolyphosphate (NBT/BCIP) substrate solution (Thermo Scientific, USA).

\section{Enzyme-linked immunosorbent assay (ELISA)}

Enzyme linked immunosorbent assays were performed using a protocol similar to that previously reported by Acquah et al. [34]. Briefly, $100 \mu \mathrm{l}$ of purified protein EBA175-RIII-V $\mathrm{L}_{\mathrm{Ll}}$ diluted to $1 \mu \mathrm{g} / \mathrm{ml}$ in PBS was coated onto NUNC maxisorp ${ }^{\mathrm{TM}}$ ELISA plates overnight at $4{ }^{\circ} \mathrm{C}$. Plates were washed four times using PBS supplemented with $0.05 \%$ Tween 20 (PBS/T) and blocked with $3 \%(w / v)$ skimmed milk powder (Marvel, UK) in PBS/T. Recombinant polyclonal human IgG (PB055) was used as a standard, at a starting concentration of $1000 \mathrm{ng} / \mathrm{ml}(100 \mu \mathrm{l})$ and serially diluted threefold for 7 additional concentrations. The plates were then incubated for an hour with $100 \mu \mathrm{l} /$ well of test plasma or a negative control (malaria naïve) sample consisting of a pool of malaria naïve plasma all diluted 200-fold at room temperature, and then washed four times with $\mathrm{PBS} / \mathrm{T}$. The plates were subsequently incubated with goat anti-human IgG-HRP secondary antibodies (Invitrogen, USA). All plates were developed by adding $50 \mu \mathrm{l}$ of $3,3^{\prime}, 5,5^{\prime}$-tetramethylbenzidine (TMB) solution for $15 \mathrm{~min}$ and then stopped with $50 \mu \mathrm{l}$ of $2 \mathrm{M}$ $\mathrm{H}_{2} \mathrm{SO}_{4}$. Absorbance of coloured products of the reaction was measured immediately after stopping the reactions at a wavelength of $450 \mathrm{~nm}$.

\section{$\lg \mathrm{G} 1$ and $\lg \mathrm{G} 3 \mathrm{ELISA}$}

A procedure similar to that described above for IgG was used with some minor modifications. Basically, the test samples were diluted 1:50 and the standard used was a pool of plasma previously identified as having high IgG1 and IgG3 concentrations at a starting concentration of 1:50 and diluted twofold for 6 extra dilutions. The plates were processed as above. The temperature setting for the $1 \mathrm{~h}$ sample incubation was increased to $37^{\circ} \mathrm{C}$ and the secondary antibodies used were goat anti-human IgG1 and IgG3, respectively.

\section{Relative avidity ELISA}

A procedure similar to the total IgG ELISA described above was used, however the plasma samples after the $1 \mathrm{~h}$ incubation were washed three times and then incubated with 2.4 M sodium thiocyanate ( $\mathrm{NaSCN})$ for $10 \mathrm{~min}$ and then subsequently washed off thrice with $\mathrm{PBS} / \mathrm{T}$ prior to the addition of the secondary antibody [26,37]. Avidity for the subclass proceeded similar to the subclass ELISA with the added $\mathrm{NaSCN}$ step.

\section{Data analysis}

The physical and chemical properties of the antigen were obtained using ProtParam [38]. ELISA data was entered into Excel, converted to antibody concentrations using ADAMSEL (Ed Remarque) and analysed using GraphPad Prism v5 and the $\mathrm{R}$ statistical software (Version 3.4.0). The frequency and other column statistics including T-tests and One way ANOVA (Kruskal-Wallis) tests were determined using GraphPad Prism v5. A non-parametric correlation (Spearman, GraphPad Prism) was used to assess correlation between age and antibody concentration and antibody avidity.

The R statistical software (Version 3.4.0) was used for the assessment of antibodies against EBA175. To project asymptomatic parasite carriage during the subsequent sampling time point in the school children, a mixed effects regression model for repeated measurements was fitted to antigen-specific antibody data using the $\mathrm{R}$ package lme4 [39]. Initially, antigen-specific antibody data and relative avidity data were $\log 2$ transformed and entered into the model as fixed effects with age as an interaction term, whilst visit time point and town were entered as random effects. This model was compared to other models that dropped the age interaction term or one of the random effects, and the best model, based on the lowest AIC values was selected for further analysis. The best model had $\log 2$ transformed antibody level and $\log 2$ relative avidity index (RAI) transformed as the fixed effect and study town as a random effect since the interaction term (age) and visit time point did not significantly contribute to the models. P-values for the intercept and fixed effect were obtained by likelihood ratio tests (with Laplace Approximation) (Table 3).

The relative avidity index (RAI) for an antibody was calculated as the ratio of the mean IgG concentration of the sodium thiocyanate-treated sample to the mean IgG concentration of the untreated sample multiplied by 100 (Avidity index $=$ [antibodies following Sodium thiocyanate $(\mathrm{NaSCN})$ treatment/antibodies without $\mathrm{NaSCN}$ treatment $] \times 100$ ). Statistical significance was defined as $P \leq 0.05$ unless otherwise stated.

Data from healthy (non parasitaemic) children were excluded from all analysis that compared antibody responses (concentration and avidity) between the threetime points. 


\section{Results}

The study used samples from 137 school children between 6 and 12 years of age. The number of asymptomatic children detected by the microscopic evaluation of thick blood smears ranged between 10.9 and $71.9 \%$ in Obom and 17.8-58.9\% in Abura (Table 1) and identified the presence of Plasmodium malariae mono infections in four children from Obom in July. Asymptomatic parasite carriage determined by PCR ranged between 59.4 and $68.8 \%$ in Obom and $18.9-75.3 \%$ in Abura (Table 1). The mean age (standard error of mean, SEM) of the school children was 9.09 (0.215) years in Obom and $8.79(0.178)$ years in Abura was not significantly different between the two sites $(\mathrm{P}>0.05$, Mann-Whitney test). The geometric mean $P$. falciparum parasite density (PD) reduced in moving from July (the peak) through October (the end of the peak) to January (the off peak) season in both sites, with PD in July being significantly different from PD in both October and January in both Obom $(\mathrm{P}<0.05$, Dunn's Multiple Comparison Test) and Abura $(\mathrm{P}<0.001$, Dunn's Multiple Comparison Test).

\section{Parasite genotyping}

The geometric mean multiplicity of infection ( $95 \%$ confidence interval) determined by genotyping the $m s p 1$ gene for asymptomatic parasite infection in Obom in July was 2.094 (1.873-2.341), which was significantly $(\mathrm{P}<0.0001$, Mann-Whitney two-tailed test) higher than 1.397 (1.238-1.577) determined in the asymptomatic children living in Abura in the same month.

Agarose gel electrophoresis of the EBA175RIII PCR amplicons yielded fragments that were either $\sim 740 \mathrm{bp}$ ('C' allele) or $\sim 820 \mathrm{bp}$ ('F' alleles). The band sizes are different from the 715 and the $795 \mathrm{bp}$ fragments that are characterized by amplification of RIII using the primers EBA1, 2, 3 and 4 [22] due to the use of the antigen cloning primers for the reactions (Additional file 1: Table S1). Parasites identified in almost all of the samples genotyped

Table 1 Characterization of study participants

\begin{tabular}{cll}
\hline & P. falciparum PCR (\%) & Microscopy (\%) \\
\hline Abura & & \\
July & 75.3 & 58.9 \\
Oct & 18.9 & 17.8 \\
Jan & 52.1 & 30.1 \\
Obom & & \\
July & 68.8 & $71.9^{\mathrm{a}}$ \\
Oct & 67.2 & 26.6 \\
Jan & 59.4 & 10.9 \\
\hline
\end{tabular}

Data presented from samples collected from 64 and 73 children living in Obom and Abura respectively

a Four children in Obom carried P. malariae mono infections predominantly belong to a single allelic family, with only one sample from Obom containing parasites belonging to both allelic families. The ' $\mathrm{F}$ '/' $\mathrm{C}$ ' allelic ratio ranged from 1.1 in Obom to 1.2 in Abura (Table 2).

\section{Production of recombinant EBA175RIII- $\mathrm{V}_{\mathrm{LI}}$}

The 1620 bp region of EBA175 (bp 2280-3900) (Fig. 2a), representing RIII-V was successfully expressed as a secreted protein in L. lactis MG1363. Recombinant EBA175RIII-V $\mathrm{L}_{\mathrm{Ll}}$ (amino acid 760-1300 of EBA175) was purified from culture supernatants on a HisTrap FF Crude column (GE Healthcare, DK) yielding a $\sim 125 \mathrm{kDa}$ product (Fig. 2b). Purified antigen was used to assess naturally acquired immune responses to EBA 175 and the relative avidity of these antibodies.

\section{Table 2 Allelic distribution of EBA175}

\begin{tabular}{llc}
\hline Allele & Abura $(\%, \mathbf{N})$ & Obom $(\%, \mathbf{N})$ \\
\hline F & $54(34)$ & $51.6(33)$ \\
C & $46(29)$ & $46.9(30)$ \\
F + C & 0 & $1.6(1)$ \\
\hline
\end{tabular}

The percentages of the alleles with the exact count in brackets

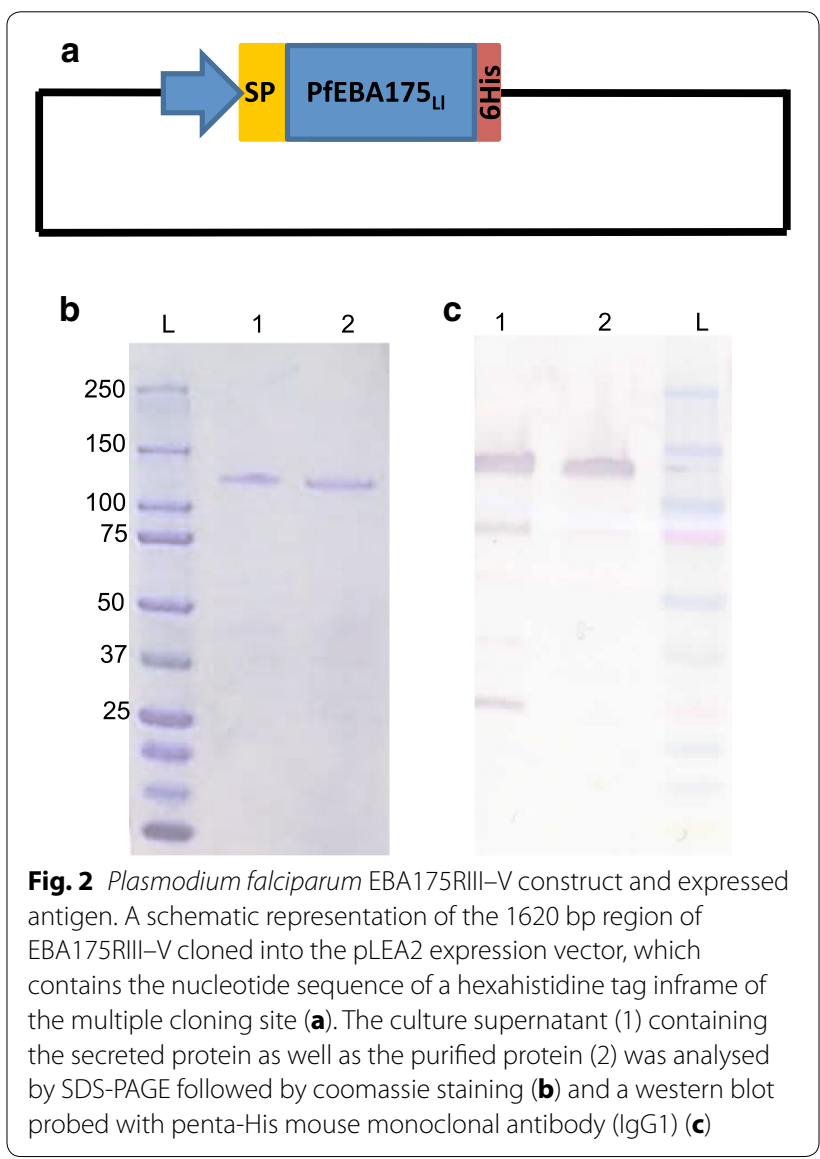


Characterization of naturally acquired antibody responses against EBA175RIII- $\mathrm{V}_{\mathrm{LI}}$

There was no significant change ( $P>0.05$, Dunn's multiple comparative test) in the median concentrations of antibodies against EBA175RIII- $\mathrm{V}_{\mathrm{Ll}}$ over the course of the changing malaria seasons in asymptomatic children from both Obom and Abura (Fig. 3a). However, antibody responses measured at each time point in Obom were significantly higher $[\mathrm{P}<0.0001$ (July), 0.0005 (October) and 0.0001 (January), Mann-Whitney test] than those measured in Abura. The general decrease in antibody concentrations observed in moving from July (the peak) to October (off-peak season) in Obom was not apparent in Abura (Fig. 3a). The trends in IgG responses to EBA175RIII- $\mathrm{V}_{\mathrm{Ll}}$ in the children were similar to those against the non-repetitive domain of P. falciparum Glutamate Rich Protein (GLURP.RO) (Additional file 2). The relative avidity indices of antibodies measured in Obom were generally lower than in Abura (Fig. 3b), however, no

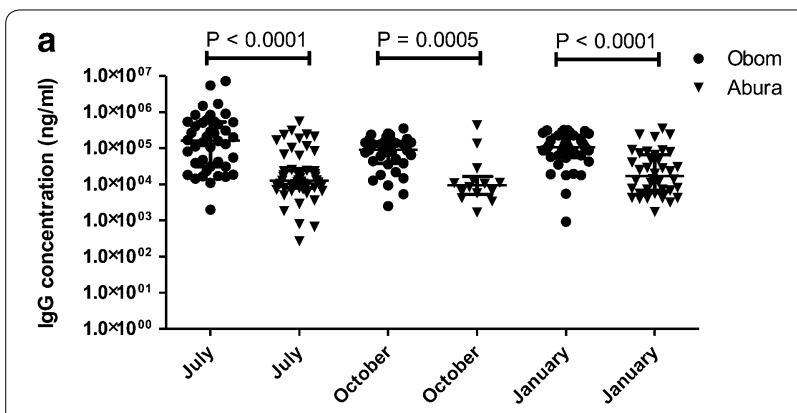

b

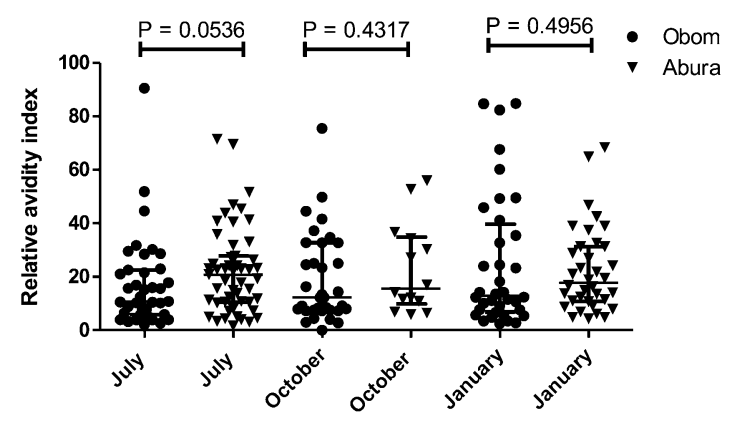

Fig. 3 Characterization of IgG responses against EBA175RIII-V $V_{L}$. Antibody concentrations ( $\mathrm{ng} / \mathrm{ml}$ ) of plasma obtained from the enrolled children from Obom and Abura (a) diluted 1:200 was determined using indirect ELISA and a EBA175RIII- $V_{L I}$ as the antigen coated onto the ELISA plate and goat anti-human IgG used as the secondary antibody. The relative avidities of these same plasma samples were determined using a modified indirect ELISA assay where an incubation of the bound plasma samples obtained from children Obom and Abura (b) were treated with sodium thiocyanide is incorporated into the protocol. Plasma samples were obtained from whole blood collected from the children during the months of July 2015, October 2015 and February 2016. Data in the graphs are represented as the median with the interquartile range significant difference was identified in the median RAI of IgG in July, October and January in either Abura or Obom ( $P>0.05$, Dunn's multiple comparative test).

The levels of IgG1 and IgG3 antibodies were significantly higher in asymptomatic children from Obom compared to the asymptomatic children from Abura (Mann-Whitney test, $\mathrm{P}=0.0002$ and 0.0410 , respectively) (Fig. 4a, b).

The concentration of IgG antibodies to EBA175RIII$\mathrm{V}_{\mathrm{Ll}}$ in asymptomatic children from both Obom and Abura did not correlate significantly with age at any time point $(\mathrm{P}>0.05$, Spearman $\mathrm{r}=0.3032,0.2171$ and 0.1597 in Obom and $-0.04814,0.3033$ and 0.04804 in Abura for July, October and January, respectively). Fewer children with high antibody avidities in July and October harboured parasites in the subsequent visit, October and January, respectively (Table 3).

\section{Discussion}

The early identification of the function RII and protective properties of antibodies against EBA175RII led to it gaining vaccine candidate status several years ago $[18,40]$. The function of RIII-V has still not been confirmed [25] and the functions of antibodies against RIII-V of EBA175 have not been as extensively characterized as RII most likely due to the dimorphic nature of RIII. EBA175 RII was earlier classified as highly conserved [41], although some studies have identified RII to be highly polymorphic $[42,43]$ and anti-EBA175R2 antibodies not to be associated with protection [44, 45]. Naturally induced antibodies against $E$. coli produced EBA175RIII-V has been found to be protective [25, 46] and mice anti-EBA175RIII-V suggested to exhibit strain-transcending activity [23]. However, more studies are needed to characterize the functions of antibodies against EBA175RIII-V.

In this study, a new recombinant EBA175RIII- $\mathrm{V}_{\mathrm{LI}}$ was produced and used to evaluate changes in the quantity and quality of naturally induced antibody responses developed against EBA175RIII-V in asymptomatic children living in communities with varying malaria transmission intensity across changing malaria seasons.

The recombinant antigen was produced in high yields, similar to that of $\mathrm{Pfs}^{2} 30 \mathrm{CO}_{L l}$ [34] and purified using a similar one-step purification process as $\mathrm{Pfs}_{2} 230 \mathrm{CO}_{L l}$ [34]. The antigen migrated as a $\sim 125 \mathrm{kDa}$ protein on a polyacrylamide (PAGE) gel (Fig. 2b, c), although the theoretically calculated size of the protein is $\sim 60 \mathrm{kDa}$. A similarly large size antigen was produced when EBA175RIII-V was expressed in E. coli [23]. This migratory pattern could be a result of the antigen having a high negative charge and a grand average of hydropathicity (GRAVY) score of - 1.384. Proteins with low GRAVY scores are noted to 

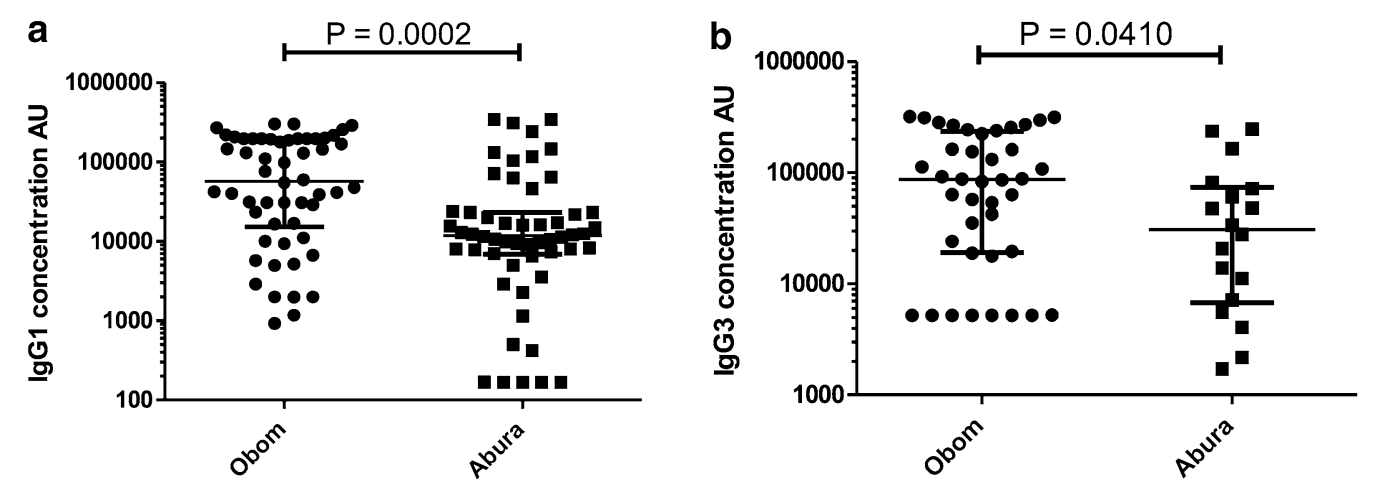

Fig. 4 Characterization of cytophilic antibody responses. IgG1 (a) and IgG3 (b) antibody concentrations to EBA175RIII-V $V_{\perp \mid}$ in asymptomatic children from Obom and Abura measured in the peak malaria season (July). Processes similar to that described in Fig. 3 were used to determine the concentrations and avidity of $\lg \mathrm{G} 1$ and $\lg \mathrm{G} 3$, the only difference was that goat anti-human $\lg \mathrm{G} 1$ and goat anti-human $\lg \mathrm{G} 3$ secondary antibodies were used in place of the goat anti-human lgG. The graphs represent the median antibody concentrations with interquartile range as error bars

Table 3 Influence of antibody concentration and relative avidity index (RAI) on the future carriage of $P$. falciparum parasites in different malaria transmission settings

\begin{tabular}{lllll}
\hline Fixed effects & Estimate std & Error & z value & $\operatorname{Pr}(>|\mathbf{z}|)$ \\
\hline (Intercept) & 0.4623 & 3.9658 & 0.117 & 0.9072 \\
$\log 2$ (Conc) & 0.1397 & 0.1345 & 1.038 & 0.299 \\
$\log 2$ (RAI) & 0.5251 & 0.2379 & 2.207 & $0.0273^{*}$
\end{tabular}

Conc. antibody concentrations in $\mathrm{ng} / \mathrm{ml}, R A /$ relative avidity index

* $\mathrm{P}<0.05$

migrate slower than expected on SDS-PAGE gels [47]. A similar phenomenon was observed after the production and purification of PfGLURP in L. lactis. PfGLURP is a negatively charged protein, which lacks tryptophan residues and migrated at $\sim 92 \mathrm{kDa}$ although the theoretical size is $\sim 55 \mathrm{kDa}$ [48]. EBA175RIII- $\mathrm{V}_{\mathrm{Ll}}$ was produced in L. lactis due to the similar codon usage between $L$. lactis and $P$. falciparum, and the fact that the fragment did not require disulfide bridge formation. Lactococcus lactis has also been used for the successful production of a number of malaria vaccine candidates including GMZ2 [49] and $\mathrm{R} 0.6 \mathrm{C}$ [35] and antigens such as $\mathrm{Pfs} 230 \mathrm{CO}_{L l}$ [34].

The geometric mean parasite density determined in July was significantly higher than that recorded in October and January in both Obom and Abura although the prevalence of children harbouring asymptomatic $P$. falciparum parasites determined by PCR remained stable over the same period in Obom. The prevalence of $P$. malariae and possibly other Plasmodium species could have been higher if more sensitive molecular tools were employed. The prevalence of $P$. malariae, the second most predominant Plasmodium species in Ghana has recently been reported to be as high as $12.7 \%$ in the tropical rainforest zone of Ghana [50]. The distribution of parasites with different eba175 alleles in the asymptomatic children from both Obom and Abura were similar, with an $\mathrm{F} / \mathrm{C}$ ratio ranging between 1.1 in Obom and 1.2 in Abura (Table 2). Genetic diversity in EBA175RIII$\mathrm{V}$ has been suggested to be limited [23] and the allelic distribution patterns found to be relatively stable over extended periods of time [51, 52]. The genotyping data did not portray the usual high prevalence of ' $\mathrm{F}$ ' allele compared to the ' $\mathrm{C}$ ' as has been previously reported in a number of West African countries including Ghana [22, $51,53]$. However, these previous studies were conducted on symptomatic samples. The geometric mean multiplicity of infection in asymptomatic children in Obom was significantly higher than that estimated for the children living in Abura, most likely due to the higher levels of malaria transmission in Obom compared to Abura.

Naturally-induced antibody responses to EBA175RIII$\mathrm{V}_{\mathrm{Ll}}$, a ' $\mathrm{F}$ ' type antigen was high in Obom and low in Abura. The even distribution of the dimorphic EBA175 alleles in both sites likely did not preferentially influence the antibody responses in either site. Naturally induced IgG responses in Obom were significantly $(\mathrm{P}<0.001$, Mann-Whitney test) higher in Obom than those measured in Abura (Fig. 3a, b) most likely due to increased exposure to parasites by children living in the perennial transmission setting, Obom compared to Abura, the seasonal transmission setting (Table 1a). The median IgG concentrations of EBA175RIII- $\mathrm{V}_{\mathrm{Ll}}$ measured in children from Obom at all the time points were significantly $(\mathrm{P}<0.0001$, Mann-Whitney test) higher than those measured in Abura, even in July when the prevalence of asymptomatic parasite carriage estimated by both microscopy and PCR was higher than in Obom. This finding supports earlier studies that used naturally acquired antibody responses to merozoite antigens 
including the apical membrane protein 1 (AMA1) and the merozoite surface protein 1 (MSP1) to differentiate between communities with different malaria transmission intensities [54-57].

No significant differences were observed in the median IgG concentrations of anti-EBA175RIII-V antibodies across the different malaria seasons in both Obom and Abura. This could be a result of boosting of antibody responses by the presence of infecting parasites in asymptomatic children, whose prevalence was maintained between October and January in both sites. This supports the suggestion that the presence of concurrent parasitaemia has been found to increase antibody responses to EBA175 antigens [24].

The IgG subclass responses against EBA175 have been suggested to be predominantly cytophilic (IgG1 and IgG3) [58, 59]. IgG1 and IgG3 responses to EBA175RIII$\mathrm{V}$ have also been associated with lower parasitaemia and protection from malaria $[17,59,60]$. In this study IgG1 and IgG3 levels in children from Obom in July were higher than those from Abura (Fig. 4), which was not surprising as total IgG levels were also significantly higher in Obom than in Abura.

The relative avidity index (RAI) of IgG antibodies against EBA175RIII- $\mathrm{V}_{\mathrm{LI}}$ was significantly inversely associated with parasite carriage during the subsequent quarterly visit (Table 3 ). The relative avidity of antibodies against EBA175RIII- $\mathrm{V}_{\mathrm{Ll}}$ in Obom was generally lower, although not significantly different from those measured in Abura ( $\mathrm{P}>0.05$, paired $t$ test) (Fig. 3c, d). The low avidity of antibodies in Obom support previous studies that have suggested impaired affinity maturation to malaria antigens in settings with high perennial exposure to malaria parasites [61]. Maturation of humoral immune responses is expected to result in the production of antibodies with increased avidity $[62,63]$, however, constant parasite carriage in areas with high perennial malaria transmission, such as Obom can result in reduced antibody affinities as has been previously reported [64].

\section{Limitations}

Plasmodium falciparum parasites were the only species of malaria parasites characterized by PCR in the study. The children were also not followed actively or passively so could have had additional exposure to P. falciparum parasites that were not captured at the sampling time points.

\section{Conclusion}

Naturally acquired IgG concentrations but not relative antibody avidities to EBA175RIII-V were significantly higher in Obom where malaria transmission is perennial than in Abura, where malaria transmission is seasonal.

\section{Additional files}

Additional file 1. Primers for cloning P. falciparum eba175RIII-V as well as for detecting and genotyping P. falciparum parasites.

Additional file 2. IgG responses to EBA175 and the Glutamate Rich Protein (GLURP.RO) measured in plasma samples obtained from the school children in October 2015 and January 2016.

\section{Abbreviations}

EBA175: Plasmodium falciparum erythrocyte binding antigen 175 (Pf3D7_0731500); bp: base pair; aa: amino acid; msp: merozoite surface protein; ELISA: enzyme linked immunosorbent assay; DBS: dried blood spot; L. lactis: Lactococcus lactis; NaSCN: sodium thiocyanate; RAI: relative avidity index.

\section{Authors' contributions}

LEA made the antigen. NAA, MTH and LEA designed the study and wrote the manuscripts. HA, FKA, and RO performed the experiments. FKA collected the samples. All authors read and approved the final manuscript.

\section{Author details}

${ }^{1}$ Noguchi Memorial Institute for Medical Research, University of Ghana, Accra, Ghana. ${ }^{2}$ Department of Medical Biochemistry, University of Ghana, Accra, Ghana. ${ }^{3}$ Department for Congenital Disorders, Statens Serum Institut, Copenhagen, Denmark. ${ }^{4}$ Centre for Medical Parasitology at Department of International Health, Immunology and Microbiology, University of Copenhagen, Copenhagen, Denmark.

\section{Acknowledgements}

The authors thank Bioneer for the use of their L. lactis expression system, all the study volunteers including the guardians of the children who gave consent. We are grateful to MR4 for providing reference gDNA for the parasite genotyping studies. We are also grateful to Dr. Asamoah Kusi, NMIMR for assistance with the statistical analysis and for critically reading the manuscript.

\section{Competing interests}

The authors declare that they have no competing interests.

\section{Availability of data and materials}

All data generated or analysed during this study are included in this published article [and its additional files].

\section{Ethics approval and consent to participate}

Permission to conduct the school survey was granted by the Directors of Education responsible for Basic Education in the two communities. Ethical approval for the study was obtained from the Institutional Review Board of the Noguchi Memorial Institute for Medical Research, where the experiments were carried out. Parental consent and assent were obtained from all the children into the study as appropriate.

\section{Funding}

This project was supported in part by a University of Ghana Grant URF/5/ILG013/2011-2012. The funders had no influence on the implementation of the project.

\section{Publisher's Note}

Springer Nature remains neutral with regard to jurisdictional claims in published maps and institutional affiliations.

Received: 20 September 2017 Accepted: 29 December 2017 Published online: 08 January 2018

\section{References}

1. WHO. World malaria report. Geneva: World Health Organization; 2016. 
2. Doolan DL, Dobano C, Baird JK. Acquired immunity to malaria. Clin Microbiol Rev. 2009;22:13-36.

3. Kinyanjui SM, Bejon P, Osier FH, Bull PC, Marsh K. What you see is not what you get: implications of the brevity of antibody responses to malaria antigens and transmission heterogeneity in longitudinal studies of malaria immunity. Malar J. 2009:8:242.

4. Bejon P, Warimwe G, Mackintosh CL, Mackinnon MJ, Kinyanjui SM, Musyoki JN, et al. Analysis of immunity to febrile malaria in children that distinguishes immunity from lack of exposure. Infect Immun. 2009;77:1917-23.

5. Kinyanjui SM, Mwangi T, Bull PC, Newbold Cl, Marsh K. Protection against clinical malaria by heterologous immunoglobulin $\mathrm{G}$ antibodies against malaria-infected erythrocyte variant surface antigens requires interaction with asymptomatic infections. J Infect Dis. 2004;190:1527-33.

6. Males S, Gaye O, Garcia A. Long-term asymptomatic carriage of Plasmodium falciparum protects from malaria attacks: a prospective study among Senegalese children. Clin Infect Dis. 2008;46:516-22.

7. Bottius E, Guanzirolli A, Trape JF, Rogier C, Konate L, Druilhe P. Malaria: even more chronic in nature than previously thought; evidence for subpatent parasitaemia detectable by the polymerase chain reaction. Trans $\mathrm{R}$ Soc Trop Med Hyg. 1996;90:15-9.

8. Laishram DD, Sutton PL, Nanda N, Sharma VL, Sobti RC, Carlton JM, et al. The complexities of malaria disease manifestations with a focus on asymptomatic malaria. Malar J. 2012;11:29.

9. Porter MD, Nicki J, Pool CD, DeBot M, Illam RM, Brando C, et al. Transgenic parasites stably expressing full-length Plasmodium falciparum circumsporozoite protein as a model for vaccine down-selection in mice using sterile protection as an endpoint. Clin Vaccine Immunol. 2013;20:803-10.

10. McCarra MB, Ayodo G, Sumba PO, Kazura JW, Moormann AM, Narum $\mathrm{DL}$, et al. Antibodies to Plasmodium falciparum erythrocyte-binding antigen-175 are associated with protection from clinical malaria. Pediatr Infect Dis J. 2011;30:1037-42.

11. Okenu DM, Riley EM, Bickle QD, Agomo PU, Barbosa A, Daugherty JR, et al. Analysis of human antibodies to erythrocyte binding antigen 175 of Plasmodium falciparum. Infect Immun. 2000;68:5559-66.

12. Chen E, Paing MM, Salinas N, Sim BK, Tolia NH. Structural and functional basis for inhibition of erythrocyte invasion by antibodies that target Plasmodium falciparum EBA-175. PLoS Pathog. 2013;9:e1003390.

13. Sim B. EBA-175: an erythrocyte-binding ligand of Plasmodium falciparum. Parasitol Today. 1995;11:213-7.

14. Badiane AS, Bei AK, Ahouidi AD, Patel SD, Salinas N, Ndiaye D, et al. Inhibitory humoral responses to the Plasmodium falciparum vaccine candidate EBA-175 are independent of the erythrocyte invasion pathway. Clin Vaccine Immunol. 2013;20:1238-45.

15. Liang H, Narum DL, Fuhrmann SR, Luu T, Sim BK. A recombinant baculovirus-expressed Plasmodium falciparum receptor-binding domain of erythrocyte binding protein EBA-175 biologically mimics native protein. Infect Immun. 2000;68:3564-8.

16. Jiang L, Gaur D, Mu J, Zhou H, Long CA, Miller LH. Evidence for erythrocyte-binding antigen 175 as a component of a ligand-blocking blood-stage malaria vaccine. Proc Natl Acad Sci USA. 2011;108:7553-8.

17. Richards JS, Stanisic DI, Fowkes FJ, Tavul L, Dabod E, Thompson JK, et al. Association between naturally acquired antibodies to erythrocyte-binding antigens of Plasmodium falciparum and protection from malaria and high-density parasitemia. Clin Infect Dis. 2010;51:e50-60.

18. Sim BK, Narum DL, Liang H, Fuhrmann SR, Obaldia N 3rd, Gramzinski $R$, et al. Induction of biologically active antibodies in mice, rabbits, and monkeys by Plasmodium falciparum EBA-175 region II DNA vaccine. Mol Med. 2001;7:247-54

19. Irani V, Ramsland PA, Guy AJ, Siba PM, Mueller I, Richards JS, et al. Acquisition of functional antibodies that block the binding of Erythrocyte-Binding Antigen 175 and protection against Plasmodium falciparum malaria in children. Clin Infect Dis. 2015;61:1244-52.

20. Lopaticki S, Maier AG, Thompson J, Wilson DW, Tham WH, Triglia T, et al. Reticulocyte and erythrocyte binding-like proteins function cooperatively in invasion of human erythrocytes by malaria parasites. Infect Immun. 2011;79:1107-17.

21. Reed MB, Caruana SR, Batchelor AH, Thompson JK, Crabb BS, Cowman AF. Targeted disruption of an erythrocyte binding antigen in Plasmodium falciparum is associated with a switch toward a sialic acid-independent pathway of invasion. Proc Natl Acad Sci USA. 2000;97:7509-14.
22. Toure FS, Bisseye C, Mavoungou E. Imbalanced distribution of Plasmodium falciparum EBA-175 genotypes related to clinical status in children from Bakoumba, Gabon. Clin Med Res. 2006:4:7-11.

23. Healer J, Thompson JK, Riglar DT, Wilson DW, Chiu YH, Miura K, et al. Vaccination with conserved regions of erythrocyte-binding antigens induces neutralizing antibodies against multiple strains of Plasmodium falciparum. PLoS ONE. 2013;8:e72504

24. Richards JS, Arumugam TU, Reiling L, Healer J, Hodder AN, Fowkes FJ, et al. Identification and prioritization of merozoite antigens as targets of protective human immunity to Plasmodium falciparum malaria for vaccine and biomarker development. J Immunol. 2013;191:795-809.

25. Chiu CY, White MT, Healer J, Thompson JK, Siba PM, Mueller I, et al. Different regions of Plasmodium falciparum Erythrocyte-Binding Antigen 175 induce antibody responses to infection of varied efficacy. J Infect Dis. 2016:214:96-104.

26. Ibison F, Olotu A, Muema DM, Mwacharo J, Ohuma E, Kimani D, et al. Lack of avidity maturation of merozoite antigen-specific antibodies with increasing exposure to Plasmodium falciparum amongst children and adults exposed to endemic malaria in Kenya. PLoS ONE. 2012;7:e52939.

27. Akpogheneta OJ, Dunyo S, Pinder M, Conway DJ. Boosting antibody responses to Plasmodium falciparum merozoite antigens in children with highly seasonal exposure to infection. Parasite Immunol. 2010;32:296-304

28. Amoah LE, Opong A, Ayanful-Torgby R, Abankwa J, Acquah FK. Prevalence of G6PD deficiency and Plasmodium falciparum parasites in asymptomatic school children living in southern Ghana. Malar J. 2016;15:388.

29. WHO. Giemsa staining of malaria blood films. In: Malaria microscopy standard operating procedure. MM-SOP-07A2016. Geneva: World Health Organization; 2016.

30. WHO. Malaria parasite counting. In: Malaria microscopy standard operating procedure. MM-SOP-09. Geneva: World Health Organization; 2016.

31. Baidjoe A, Stone W, Ploemen I, Shagari S, Grignard L, Osoti V, et al. Combined DNA extraction and antibody elution from filter papers for the assessment of malaria transmission intensity in epidemiological studies. Malar J. 2013;12:272.

32. Singh B, Bobogare A, Cox-Singh J, Snounou G, Abdullah MS, Rahman HA. A genus- and species-specific nested polymerase chain reaction malaria detection assay for epidemiologic studies. Am J Trop Med Hyg. 1999;60:687-92.

33. Ayanful-Torgby R, Oppong A, Abankwa J, Acquah F, Williamson KC, Amoah LE. Plasmodium falciparum genotype and gametocyte prevalence in children with uncomplicated malaria in coastal Ghana. Malar J. 2016;15:592.

34. Acquah FK, Obboh EK, Asare K, Boampong JN, Nuvor SV, Singh SK, et al. Antibody responses to two new Lactococcus lactis-produced recombinant Pfs $48 / 45$ and Pfs 230 proteins increase with age in malaria patients living in the Central Region of Ghana. Malar J. 2017;16:306.

35. Theisen M, Roeffen W, Singh SK, Andersen G, Amoah L, van de VegteBolmer $\mathrm{M}$, et al. A multi-stage malaria vaccine candidate targeting both transmission and asexual parasite life-cycle stages. Vaccine. 2014:32:2623-30.

36. Singh SK, Roeffen W, Andersen G, Bousema T, Christiansen M, Sauerwein $R$, et al. A Plasmodium falciparum 48/45 single epitope R0.6C subunit protein elicits high levels of transmission blocking antibodies. Vaccine. 2015:33:1981-6.

37. Wilson KM, Di Camillo C, Doughty L, Dax EM. Humoral immune response to primary rubella virus infection. Clin Vaccine Immunol. 2006;13:380-6.

38. Gasteiger E, Hoogland C, Gattiker A, Duvaud S, Wilkins MR, Appel RD, et al. Protein identification and analysis tool on the ExPASy server. In: Walker JM, editor. The proteomics protocols handbook. New York: Humana Press; 2005. p. 571-607.

39. Bates $D$, Maechler M, Bolker B, Walker S. Fitting linear mixed-effects models using \{lme4\}. J Stat Softw. 2015;67:1-48.

40. Jones TR, Narum DL, Gozalo AS, Aguiar J, Fuhrmann SR, Liang H, et al. Protection of Aotus monkeys by Plasmodium falciparum EBA-175 region II DNA prime-protein boost immunization regimen. J Infect Dis. 2001;183:303-12.

41. Liang H, Sim BK. Conservation of structure and function of the erythrocyte-binding domain of Plasmodium falciparum EBA-175. Mol Biochem Parasitol. 1997:84:241-5. 
42. Ozwara H, Kocken CH, Conway DJ, Mwenda JM, Thomas AW. Comparative analysis of Plasmodium reichenowi and P. falciparum erythrocytebinding proteins reveals selection to maintain polymorphism in the erythrocyte-binding region of EBA-175. Mol Biochem Parasitol. 2001;116:81-4.

43. Baum J, Thomas AW, Conway DJ. Evidence for diversifying selection on erythrocyte-binding antigens of Plasmodium falciparum and P. vivax. Genetics. 2003;163:1327-36.

44. Noland GS, Hendel-Paterson B, Min XM, Moormann AM, Vulule JM, Narum DL, et al. Low prevalence of antibodies to preerythrocytic but not blood-stage Plasmodium falciparum antigens in an area of unstable malaria transmission compared to prevalence in an area of stable malaria transmission. Infect Immun. 2008;76:5721-8.

45. Osier FH, Fegan G, Polley SD, Murungi L, Verra F, Tetteh KK, et al. Breadth and magnitude of antibody responses to multiple Plasmodium falciparum merozoite antigens are associated with protection from clinical malaria. Infect Immun. 2008;76:2240-8.

46. Toure FS, Deloron P, Migot-Nabias F. Analysis of human antibodies to erythrocyte binding antigen 175 peptide 4 of Plasmodium falciparum. Clin Med Res. 2006:4:1-6.

47. Shirai A, Matsuyama A, Yashiroda Y, Hashimoto A, Kawamura Y, Arai R, et al. Global analysis of gel mobility of proteins and its use in target identification. J Biol Chem. 2008;283:10745-52.

48. Theisen M, Vuust J, Gottschau A, Jepsen S, Hogh B. Antigenicity and immunogenicity of recombinant glutamate-rich protein of Plasmodium falciparum expressed in Escherichia coli. Clin Diagn Lab Immunol. 1995;2:30-4.

49. Theisen M, Soe S, Brunstedt K, Follmann F, Bredmose L, Israelsen H, et al. A Plasmodium falciparum GLURP-MSP3 chimeric protein; expression in Lactococcus lactis, immunogenicity and induction of biologically active antibodies. Vaccine. 2004;22:1188-98.

50. Owusu EDA, Brown CA, Grobusch MP, Mens P. Prevalence of Plasmodium falciparum and non-P. falciparum infections in a highland district in Ghana, and the influence of HIV and sickle cell disease. Malar J. 2017; 16:167.

51. Soulama I, Bougouma EC, Diarra A, Nebie I, Sirima SB. Low-high season variation in Plasmodium falciparum erythrocyte binding antigen 175 (eba-175) allelic forms in malaria endemic area of Burkina Faso. Trop Med Int Health. 2010;15:51-9.

52. Perce-da-Silva DS, Banic DM, Lima-Junior JC, Santos F, Daniel-Ribeiro CT, de Oliveira-Ferreira J, et al. Evaluation of allelic forms of the erythrocyte binding antigen 175 (EBA-175) in Plasmodium falciparum field isolates from Brazilian endemic area. Malar J. 2011;10:146.

53. Cramer JP, Mockenhaupt FP, Mohl I, Dittrich S, Dietz E, Otchwemah RN, et al. Allelic dimorphism of the erythrocyte binding antigen-175 (eba-175) gene of Plasmodium falciparum and severe malaria: significant association of the C-segment with fatal outcome in Ghanaian children. Malar J. 2004;3:11.

54. Stewart L, Gosling R, Griffin J, Gesase S, Campo J, Hashim R, et al. Rapid assessment of malaria transmission using age-specific sero-conversion rates. PLOS ONE. 2009:4:e6083.

55. Bousema T, Youssef RM, Cook J, Cox J, Alegana VA, Amran J, et al. Serologic markers for detecting malaria in areas of low endemicity, Somalia, 2008. Emerg Infect Dis. 2010;16:392-9.

56. Tongren JE, Drakeley CJ, McDonald SL, Reyburn HG, Manjurano A, Nkya WM, et al. Target antigen, age, and duration of antigen exposure independently regulate immunoglobulin $\mathrm{G}$ subclass switching in malaria. Infect Immun. 2006;74:257-64.

57. Supargiyono S, Bretscher MT, Wijayanti MA, Sutanto I, Nugraheni D, Rozqie $\mathrm{R}$, et al. Seasonal changes in the antibody responses against Plasmodium falciparum merozoite surface antigens in areas of differing malaria endemicity in Indonesia. Malar J. 2013;12:444.

58. Ahmed Ismail H, Tijani MK, Langer C, Reiling L, White MT, Beeson JG, et al. Subclass responses and their half-lives for antibodies against EBA175 and PfRh2 in naturally acquired immunity against Plasmodium falciparum malaria. Malar J. 2014;13:425.

59. Weaver R, Reiling L, Feng G, Drew DR, Mueller I, Siba PM, et al. The association between naturally acquired lgG subclass specific antibodies to the PfRH5 invasion complex and protection from Plasmodium falciparum malaria. Sci Rep. 2016;6:33094

60. Stanisic DI, Fowkes FJ, Koinari M, Javati S, Lin E, Kiniboro B, et al. Acquisition of antibodies against Plasmodium falciparum merozoites and malaria immunity in young children and the influence of age, force of infection, and magnitude of response. Infect Immun. 2015;83:646-60.

61. Ssewanyana I, Arinaitwe E, Nankabirwa Jl, Yeka A, Sullivan R, Kamya MR, et al. Avidity of anti-malarial antibodies inversely related to transmission intensity at three sites in Uganda. Malar J. 2017;16:67.

62. Perciani CT, Peixoto PS, Dias WO, Kubrusly FS, Tanizaki MM. Improved method to calculate the antibody avidity index. J Clin Lab Anal. 2007;21:201-6.

63. Tutterrow YL, Salanti A, Avril M, Smith JD, Pagano IS, Ako S, et al. High avidity antibodies to full-length VAR2CSA correlate with absence of placental malaria. PLoS ONE. 2012;7:e40049.

64. Cadman ET, Abdallah AY, Voisine C, Sponaas AM, Corran P, Lamb T, et al. Alterations of splenic architecture in malaria are induced independently of toll-like receptors 2, 4, and 9 or MyD88 and may affect antibody affinity. Infect Immun. 2008;76:3924-31.

\section{Submit your next manuscript to BioMed Central and we will help you at every step:}

- We accept pre-submission inquiries

- Our selector tool helps you to find the most relevant journal

- We provide round the clock customer support

- Convenient online submission

- Thorough peer review

- Inclusion in PubMed and all major indexing services

- Maximum visibility for your research

Submit your manuscript at www.biomedcentral.com/submit
() Biomed Central 